\title{
THE PERSUASIVE USE OF WORDS BY LEADERS IN THE CREATION OF THE OWN IDENTITY VERSUS THE IDENTITY OF THE OPPONENT IN MOMENTS OF CONFLICT
}

\author{
Aurelia Carranza Márquez
}

\section{MAIN GOAL}

This work is will concentrate on the different strategies used by political and spiritual leaders in order to persuade their community that they are the appropriate leaders and that their decisions should be followed in moments of crisis. The persuasive strategies used in order to involve the addressees are mainly based in the legitimization of their attack on the enemy. In order to achieve such legitimization, the image of the "other" is usually created, and in this context, the choice of words by the leaders is very relevant. Therefore, this work will focus on the importance of vocabulary in moments of conflict, in particular, the conflict created after the attacks of September 11, 2001 in the U.S.A.

The "other" is normally depicted as something apart from the addressee. This could be considered a way of avoiding sympathy with the opponent, and of obtaining the support of the addressee. No matter how absolutist a system is, the leaders always depend to a certain extent on the opinion of their community and take care of their image.

\section{CORPUS}

The corpus under study consists of three main contemporary texts and other texts belonging to different periods of history, modern times included. The main texts are the speech by Bush on TV the night of September 11, 2001; a pamphlet by the Revolutionary Communist Party U.S.A.; and a speech by Osama bin Laden three weeks after the attack which was translated into English in the media. These texts belong to the moment of crisis used as the basis of the analysis, that of the attack on the World Trade Center in New York City and the Pentagon in Washington D.C., and the political reactions it caused at a discursive level.

Some complementary texts will be used in order to support some of the ideas presented in the study. Some of these texts are some speeches by different American Presidents, like John F. Kennedy or Henry Kissinger on foreign policy; a sermon by the Puritan priest Jonathan Edwards; different newspapers; and communist and pacifists claims on the Internet, among other sources.

The speech by Bin Laden is not the original one, but a translation into English. The original one was uttered in Arabic. Unfortunately, I do not speak this language, but I think 
that, for the purpose of this study, it is more interesting to analyze the text in its target language (English) than in its source language. It is the impact on the American public and their subsequent reactions that interest me the most. (Besides, I do not have access to the view of the Arab people and I would exceed the limits of this study on discourse 'in English').

\section{ARRANGEMENT OF THE WORK AND METHOdOLOGY}

In order to study the different texts, the basis for the analysis will be the model presented by Norman Fairclough in his work Language and Power (1989) and Critical Discourse Analysis (1995). I have chosen his model because it conforms one of the main approaches within the field of Discourse Analysis, namely the CDA (Critical Discourse Analysis) perspective, specifically designed for the analysis of discourse from a sociological view where power relationships are most relevant, being political discourse of one its main objects of study.

Fairclough's model distinguishes three different levels of analysis: description, interpretation and explanation. However, following the whole model exceeds the goal of this work. Consequently, I will concentrate on one aspect of one of the three levels described by Fairclough. Particularly, I will focus on the part devoted to the study of vocabulary in political texts. This study is described in the level that the author calls description. But first, I will go through this model very briefly.

Description is the level that is most closely connected to the text. It analyses the grammatical, semantic and conversational features. It is mostly related to the form. A brief summary of the steps this level implies is:

\begin{tabular}{|l|l|l|}
\hline \multicolumn{1}{|c|}{ VOCABULARY } & GRAMMAR & TEXTUAL STRUCTURES \\
\hline $\begin{array}{l}\text { Experiential values: } \\
\text { - Classification schemes } \\
\text {-Rewording/Overwording } \\
\text { - Synonymy/Antonymy }\end{array}$ & $\begin{array}{l}\text { Experiential values: } \\
\text { - Agency } \\
\text { - Processes } \\
\text { - Active/passive sentences } \\
\text { - Negation }\end{array}$ & Interactional conventions \\
\hline $\begin{array}{l}\text { Relational values: } \\
\text { Euphemistic expressions } \\
\text { - Formality }\end{array}$ & $\begin{array}{l}\text { Relational values: } \\
\text { - Modes (moods) } \\
\text { - Modality } \\
\text { - Pronouns }\end{array}$ & Control of the turns \\
\hline Expressive values & $\begin{array}{l}\text { Expressive values: } \\
\text { - Expressive modality }\end{array}$ & Larger-scale structures \\
\hline Metaphors & $\begin{array}{l}\text { Connection: } \\
\text { - Connectors } \\
\text { •Coordination/Sulbordlination }\end{array}$ & \\
\hline
\end{tabular}




\section{The ANAlysis}

According to Fairclough 1989 vocabulary has four different types of values: experiential, relational, expressive and metaphorical.

\subsection{Experiential values of Vocabulary}

"A formal feature with experiential value is a trace of and a cue to the way in which the text producer's experience of the natural or social world is represented." Fairclough distinguishes different sections in the analysis of experiential values of vocabulary. In this work, we will see three sections. The first one is related to classification schemes in terms of which vocabulary is organized in discourse types and their ideological implications. The second one will concentrate on the study of overwording and rewording of the texts under analysis. And in the last one we will examine cases of synonymy, hyponymy, and antonymy.

\subsubsection{Classification schemes}

The lexical items used in a text reflect the connection between the producer and the reality he is representing (Fairclough 1985). In order to study the vocabulary used in the texts under analysis, I have organized the lexical items in terms of relation to central topics. I will analyze only some examples. These topics are summarized in the following outline. It does not reflect all topics in the texts, but I hope it will facilitate the analysis of the meanings and relations assigned to the words in these texts.

\subsubsection{God}

4.1.1.1.1. The Pious God: The Lamb

4.1.1.1.2. The Angry God

4.1.1.1.2.1. An eye for an Eye

4.1.1.1.2.2. The Sword

4.1.1.2. Devil

4.1.1.2.1. The Threat

4.1.1.2.2. Evil attributes

4.1.1.3. God versus Evil: The Crusades

4.1.1.4. Ideology: Capitalism

4.1.1.5. Moral: Obligation and Responsibility

\subsubsection{God}

In all texts except for that of the Communist Party, God is mentioned as the source or support of what is being reported. However, we do not always find God with the same attributes. Sometimes it is presented as the Pious God that is reflected in the New Testament in the personification of Jesus Christ, and some other times, we find the Angry God that is depicted in the Old Testament.

\footnotetext{
${ }^{1}$ See N. Fairclough, Language and Power, London, Longman, 1989.
} 


\subsection{THE PIOUS GOD}

The Pious God is presented under some symbols such as that of the Lamb for sacrifice. God, personified as Christ, was the victim of men for men, and this role of victim is presented in many texts.

"The victims were in airplanes or in their offices: secretaries, business men and women, military and federal workers, moms and dads, friends and neighbors" (Bush). In this list, the speaker starts in a professional level and then moves towards a more private and familiar one. The catalogue of victims presented is very democratic. It puts together people that in their professional lives belong to different hierarchical positions. The point is that it does not matter if they were powerful or not, they are all dead now. The fact of moving from the professional to the familiar level humanizes the victims. The implication could be that it could happen to anyone. They were human beings and had a family, just like the addressee.

The innocence component of the lamb is sometimes made explicit, "Millions of innocent children are being killed...without committing any sins" (Bin Laden). In this example, the innocence component is present in three different ways. The adjective innocent is the first and most explicit reference to this component. Also, many people were being killed, but the speaker decides to concentrate on the children. Children traditionally have been considered innocent by nature; therefore, the adjective that modifies this noun is somehow redundant. And finally, the speaker decides to emphasize a particular type of innocence, the religious one. Innocent as opposed to sinner. In this sense, the people killed in the Twin Towers are not considered innocent, since they are infidels and their leader, George W. Bush, is "the head of infidels worldwide".

\subsection{Angry Grod}

Bin laden also uses the religious theme of a God of revenge. It has already been analyzed how he uses the image of the lamb of sacrifice to describe their situation. However, when he describes their reaction, there is no turning the other cheek.

\subsection{An Eye for an Eye}

The idea of deserving and paying back for offenses is present in the Bible in the Talion law: an eye for an eye, a tooth for a tooth.

Bin Laden's text is structured on the basis of comparisons, some are explicit, and some others are not. These comparisons highlight the fact that there is no balance between parts. The first comparison is explicit, "What America is tasting now is something insignificant compared to what we have tasted for scores of years" (line 4). The adjective insignificant is emphasizing the lack of balance between America's suffering and that of the Islamic community. This is also reflected in way the speaker refers to the behavior of the International Community. They are not being fair. They support America over them. Words like, debauched, injustice, support, justification, condemnation, reflect the idea that they are supporting the wrong people.

Numbers are also used to reinforce his claim of injustice. When the speaker refers to the damage caused by America, he speaks of, hundreds of thousands, but when he speaks about the damage caused to America, the number is reduced to dozens. This strategy of attacking 
the opponent personally is known as Argumentum ad hominem. Actually, in this case a variant is used, the tu quoque argumentation, that is, you too. The speaker accuses the opponent of doing the same things, or even worse things than those it concerns about (Van Eermeren \& Grootendorst 1992).

The last comparison in the text is the last statement, the oath. Here, he swears by God that America will not have peace until they have peace. This is a time comparison, not before. The goal is to restore the balance lost by the abuses of America and its supporters, with the help of God.

In the text, he tries to identify the anger of the Islamic Community with God's anger, "May God show them His wrath and give them what they deserve." Thus, he is legitimizing their right to hit back in the same measure and with the same strength of his offenders.

\subsection{The Sword}

A sword is no longer a valid war weapon. However, this word has a symbolic meaning in a religious context. The image of a sword falling over the sinner has been found in other radical religious discourses. Words like degradation, humiliation, commit, sins are related to this context of sinners being punished, which is the idea the speaker may be trying to convey. An example of this type of discourse is that of the Calvinist pastor Jonathan Edwards. His discourse "Sinners in the hands of an Angry God" was preached to a rural congregation at Enfield, Massachusetts, on July 8, 1741. In this discourse he affirms, "The wrath of God burns against them...the pit is prepared...The glittering sword is whet, and held over them, and the pit hath opened its mouth under them." Bin Laden, however, makes a more specific use of this religious image in a particular context, "When the sword comes down (on America), after 80 years...". Here, Doomsday has already arrived and America has been damned for its sins. God's wrath has shown its power.

\subsubsection{The Devil}

The idea of the Devil will be analyzed under a wide perspective. That is, not just from a biblical point of view, but also from a good-bad perspective. In this dichotomy, what is considered negative and destructive is bad, and it will be regarded as the Devil.

Although there are many allusions to God, the allusions to the Devil are also very frequent and important. It could be said that some texts are God oriented whereas some other texts are Devil oriented. As we have already analyzed in the previous section, Bin Laden's text contains many allusions to God, therefore, it could be said that it is God oriented. The RCP text, on the contrary, is Devil oriented. And Bush's speech is something in between. It could be said that the ones who consider themselves victims base their discourse on the evilness of their opponents. The agents of violent actions, on the contrary, justify themselves and insist that they did as God dictated.

Bush insists that evil forces attacked his country, "Thousands of lives were suddenly ended by evil", "Today, our nation saw evill", "The search is underway for those who are behind these evil acts". He is placing his country in the position of a victim at the beginning of the speech. Nevertheless, towards the end, God is introduced as a source of support to defeat evil. In other words, when the speakers/writers suggest themselves as agents of future actions, God, as in the case of Bin Laden, becomes the protagonist as the 
main supporter of those actions. However, here, we do not find an angry God asking for revenge. This discourse is more subtle and advocates for the role of victim even when they mean to hit back. We find God protecting His flock. In his discourse, Bush utters psalm 23: "Even though I walk through the valley of the shadow of death, I fear no evil for you are with me". The role of God as a protective entity is present although the first part of this psalm is not mentioned, "The Lord is my shepherd: I shall not want".

The opposition God-Evil is not simple, especially when it is being used to explain complex events. Below I analyze some implications of evilness.

\subsection{The Threat}

Fear can be regarded as an emotional persuasive appeal. (Stiff 1994). The texts under analysis are meant to be persuasive. Bush could be urging the population not to question him as a leader and to believe that the disaster was not his fault, but the result of a conspiracy against the greatness of America. Bin Laden may be trying to convince the Islamic community to support him in his Holy War. And the RCP criticizes the government with the expectation of moving the American citizens to rebellion against their political system. Now I will analyze a threat and see in which sense it could be persuasive.

"...for the children whose worlds have been shattered, for all whose sense of safety and security has been threaten" (Bush). This threat, although it is not explicitly mentioned in this sentence, may have its roots in the fear of the devil. Throughout the text, allusions to the agency of evil to the attack are found, "Thousands of lives were suddenly ended by evil" (line 4). Therefore, it could be said that the threat has its roots in evil forces. However, what I am going to concentrate on in this example is not the source of the threat, but what is being threatened.

I would like to analyze the stereotype used by Bush: the Promised Land. The text is full of references to the myth of the American dream, which is established from the very first sentence. A word chain throughout the text reinforces this idea: way of life, freedom, opportunity, great nation, justice, peace, good, just. All these lexical references support the possibility of hyponymy when the speaker refers to safety in the threat. Part of that dream is the untouchable nature of American citizens. In other words, the audience might be prepared to understand American dream when speaking of security in the final part of his speech.

This threat is very serious. It is endangering the traditional foundation of the country. Those who wanted to improve their lives moved there attracted by a land of opportunity, and those who were either politically or religiously prosecuted in their original countries went there looking for freedom.

Something that should be taken into account is that this threat could be an interpretation of Bush. At the beginning of the speech he says that the American way of life and freedom was attacked, "Good evening. Today, our fellow citizens, our way of life, our very freedom came under attack..." (line 1), but the truth is that it was the Twin Towers and the Pentagon that were attacked. Bin laden had not spoken so far. Bush, who belongs to the promisedland way of life, shares his fears with his citizens. Therefore, I would say that it is Bush instead of Bin Laden the agent of this threat in a wide sense. According to Atkinson, there are three parts in a fear appeal: fear, threat and sense of efficacy. Maybe, Bush is searching 
for that sense of efficacy. Americans may perceive, that if they do as he says, then, their traditional way of life will be maintained.

\subsection{Evil attributes}

All texts under study describe their opponents as cruel creatures. In some cases, the description has religious implications, and they attribute to their enemy features that traditionally have been used to describe the Devil. In some other cases, religious allusions are not so clear, and the opponent is presented as a beast that is very close to the Devil. This specification between religious and non-religious derives from the fact that the Revolutionary Communist party declares itself atheistic and in the texts I have analyzed from them, the image of the Devil is only used to criticize the use their opponents make of it. However, the creature they describe here is very close to it.

Bloody, arrogant, cold-hearted, beast, boast, preying, arrogant, lying. These words personify a political system into a beast that very much reminds us of the Devil. The consequences of such system are also described in the same negative terms, horrors, tears, pain, suffering, revenge, terror, fear, poison. The mood of the pamphlet is catastrophistic. It describes the state of their country and of the world as a hell, and the government of Bush as the leader of that hell. The tu quoque argumentation is used. The idea of evil forces attacking was presented three days earlier on TV. The people were very sensitive by this time, and the writer may be trying a shock therapy to get the attention of the reader.

\subsubsection{God versus Evill. The Crusades}

The images of God and Evil have been already analyzed independently. Now, the tension between them is going to be the goal of this study (in particular, one consequence of this tension: the Crusades). Crusades are not something new. Since the first one in the end of 11 th century, there have been many more. Some of them have been official, and some others have not. But in any case, all of them have had something in common. Economic and religious interests mingle, and it is the religious claim that mostly appears in the discourse generated in the conflict.

The economic motivation under a religious and pious discourse usually generates the introduction of the term crusade in the discourse. In the conflict generated in September 11, the term crusade was used, and is still being used in the present. In order to present some examples of the "Crusade" aspect of the conflict, I will move to more recent texts, To hell with the Bush-Cheney war crusade!, (communist Voice, October 26, 2002), The current war drive is not merely the personal crusade of Bush... (Detroit Worker's Voice, January 10, 2003).

Two important claims in a crusade are: God is on our side, and we are his chosen people. This implies the inferiority of the opponents; God wants us to fight them in His name.

In the first claim, on the one hand, the inferiority of the opponents is materialized in the degradation, dehumanization or alienation that discourse generates. They are called beasts (RCP), evil (Bush), infidels, cowards (Bin Laden). And, on the other hand, there is an exaltation of the qualities of the community of the speaker, A great people (Bush), innocent child (Bin Laden). 
There is also an exaltation of the idea of Community itself. Segregation versus integration is the tool. In order to avoid sympathy with the opponents, they are expelled from the community and presented as something awkward and separated from the addressee, "Hypocrisy stood in force behind the head of infidels worldwide...America and those who are with it...God keep you away from the" (lines 26-28).

One example of integration is found in "Latino", a newspaper in Spanish from Detroit and Toledo. The front page starts with the following title: "Detroit tiene sus heroes hispanos" "The Hispanic community in these cities is very big, but still, there are many integration problems. They have legal problems with their papers and many of them feel alienated from the community, even though they have been living there for a long period of time. Their participation in the War of Iraq is a way of being part of the community. The claim here is not just that they are as helpful as any other member of the community, but rather that they are especially valuable. This connotation is provided by the term heroe. Heroes by nature do extraordinary things for just causes. They are legitimizing the war as something right, and thus, they are supporting the war as proof that they are part of the community.

Very much related to the second claim, a warfare vocabulary can be found in the texts. Blood, attacked, killers, force, crime, victorious, armies (Bin Laden) mass murder, attack, powerful, enemies, defend (Bush) bombs, cruise missiles, military actions, warpath, mass murderers, crimes, concentration camps...(RCP). The expression mass murderers is used by both, the RCP and Bush. Nevertheless, Bush is using it to describe terrorists whereas the RCP is using it to describe Bush's government. This is one example of the strategy followed by the RCP that consists in using Bush's own words against him in an attempt to make him lose his credibility.

The main difference between these texts is that Bush is talking about a hypothetical war started by the attack, whereas the other texts are talking about real wars which have been taking place for a long time. If we take into account the image of innocent victim he is trying to transmit to the addressee, Bush's use of this vocabulary is more symbolic than that of the other speakers.

As a last remark in this section of war and religion, I would like to give an example of how the population internalizes the message that both ideas are inseparable. This an obituary from a latin newspaper from Ohio and Michigan, La prensa (vol. 33 No. 3, April 2, 2003):

IN LOVING MEMORY OF OUR BROTHER JOHN G. GARCIA, SR.

You fought your battle, as always, with faith, courage, and tenacity. But the Lord saw you were weary and called you home. You made us proud. We will love you and miss you always. Your family: Ernestine "Tina"...

\subsubsection{Ideology}

Ideology is an important component in political discourses. The ideological aspect that I am going to analyze is capitalism. Therefore, the text by the RCP is going to be the

\footnotetext{
${ }^{2}$ Volume 10, April 3 (2003).
} 
protagonist. Words like financial and imperialism come together with military actions, rentless global exploitation or countless crimes. They are in the same context implying that all those horrible things are derived from the capitalist system. A very expressive example of the way the writer views the system is "The rulers capitalize on our pain and ask the people to pray with them." This quotation has two parts. The first one is the first sentence in the additive construction. Here, the term capitalize is very meaningful since it is lexically related to capitalism and it appears in the same construction as pain. It could imply that capitalist systems bring forth pain to the citizens. In the second part, the allusion to the prayer is directly connected to the speech by Bush in which he explicitly asks the population to pray, "Tonight, I ask for your prayers". The addition of two sentences which are semantically opposed, one implying a system that hurts and does not care for people, and one implying a system that is religiously concerned and cares for the population, generates a contradiction. It stands for the contradiction of the government. That is, the government is contradictory, it should not be trusted.

\subsubsection{Moral: Obligation and Responsibility}

This last topic is very recurrent in political discourse. There are many memorable quotations that almost everybody can recite more or less accurately. For instance, "Ask not what your country can do for you, ask what you can do for your country" (John F. Kennedy) ${ }^{3}$.

In the speech by Bush, there is a part in which responsibility is not explicitly mentioned, but it is somehow implied, "This is a day when all Americans from every walk of life unite in our resolve for justice and peace. America has stood down enemies before, and we will do so this time. " (lines 41-42). In order to perceive the obligation component, we need to go back in history of the U.S.A. and remember some discourses American citizens have been exposed to.

Traditional discourses are important in relation to the way a society creates its values. Isocrates already implied that speaking can help train a moral consciousness. This idea is still valid for modern authors. An example is the theory of "symbolic convergence" (Bormann 1982). According to it, the terms we use to describe our world affect the nature of our observations. When that language is repeated to others over the time, a chain effect takes place with the result of symbolic convergence ${ }^{4}$.

First, we will see what the term American implies. For this, we are going to read some examples of the use of this term, "We are Americans, determined to defend the frontiers of freedom by an honorable peace if possible, and by armies if arms are used against us"

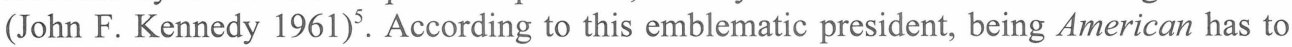
do with honorability, freedom, and the power to defend such freedom all over the world.

\footnotetext{
${ }^{3}$ Inaugural address as U.S. president, 1961.

${ }^{4}$ In C. De Landtsheer \& O. Feldman, Ed. Behond Public Speech and Symbols. Explorations in the Rethoric of Politicians and the Media, Westport, Praeger, 2000

${ }^{5}$ See M. Ball, "Political Language and the Search for an Honorable Peace: Presidents Kennedy and Johnson, Their Advisers, and Vietnam Decisions Making", Chapter 3 of Beyond Public speech and symbols, 2000
} 
This idea of the defense of the world is also present in a book written by another important figure: Henry Kissinger. "We have the capacity to enable allies and friends to live with a sense of security; we possess the assets to advance the process of building an international order of cooperation and progress. We must do so." (Kissinger 1977). This last idea of obligation is developed in the same book: "We must prevent the Soviet Union from translating its growing strength into global or regional preponderance. But we must not do so without escalating every cisis into a massive confrontation...At the same time, we have an historic obligation to mankind to engage the Soviet Union in settlements of concrete problems and to push back the shadow of nuclear catastrophe" ${ }^{6}$.

From this, it could be derived that the U.S. considers itself the guardian of the world on the basis of their morality, freedom, honorability, and on the basis of their strength: "For we, the strongest free nation..." (Kissinger).

After this short flashback in history, the term American has a wide dimension. It implies the moral honorability of a superior nation. The honorability of the country obliges its citizens to behave in consequence. All those who consider themselves Americans, which is an honor, have the responsibility of supporting their country in defense of peace and security in their country. Supporting their country means supporting their government, the expression of the American wish on a Ballot Box.

\subsubsection{Rewordling, overwording}

If we find any of these processes in a text, we should be aware of the context and the element from which rewording and overwording takes place. Language has a tendency towards economy, thus when the speaker dedicates extra energy to something that could be said with fewer words, that could imply that there is an additional meaning or at least, some emphasis or preoccupation with what is being said.

\subsubsection{REWORDING}

We will see some examples of rewording from Bin Laden: "Hypocrisy stood in force behind the head of infidels worldwide, behind the cowards of this age, America and those who are with it." (Bin Laden). In this sentence, the word infidel is reworded as coward and as America and those who are with it. There are two rewordings in just one sentence. The implication of infidel is clear since this is a speech with a high religious component, and the opponent does not share the same religion. However, coward could lead to different interpretations. The interpretation that I suggest is based on the text.

This word is reworded a second time into America and its allies, and I am going to start my analysis from here. This phrase implies the idea of cooperation, but in a negative way. Throughout the text, the idea of injustice has been emphasized in relation to the abuses of the U.S.A., and especially, in relation to the behavior of the International Community in this respect. They claim they are supporting the criminals instead of the victims, "They supported the butcher over the victim, the oppressor over the innocent child." The insistence on this fact is recurrent. The speaker may be suggesting that international support provides the U.S. with strength and resolution to abuse other countries. They are cowards because they are abusive and they are not alone, as the Islamic community is. This

\footnotetext{
${ }^{6}$ See H. Kissinger, American Foreign Policy, N.Y., W.V. Norton \& Company inc. 1977
} 
accusation is giving part of the responsibility to the International Community, and the implication could be that they are many against a few, and that is cowardly.

\subsubsection{OVERWORDING}

Now, we are going to analyze an example of overwording by the RCP:

"Now, besides the horrors that they have perpetuated against the people around the world-horrors that multiply the tears shed in NY and Washington a thousand times--these cold-hearted imperialists have called forth the same kind of devastation in the belly of their own beast."

English speakers, in their use of language, have a tendency to avoid very long and complicated constructions. In this sense, the sentence above is not commonly found in written texts. Part of the length is due to a process of overwording.

The logic of this pamphlet is mainly based on the fact that what happened in September 11 was the fault of the government. They accuse it of inflicting so much pain on the people of many countries that they decided to hit back. The overwording is emphasizing the terrible pain that the U.S. has caused and that they are not innocent victims. They do it through the expansion of the word horror. Besides, the title of the pamphlet is "The horrors that come from this horrible system", and all this emphasis on this word related to pain in the U.S. and in the world reflect the catastrophic view that this party has of capitalism. Notice that the word imperialism appears in this context of "horrors" together with the modifier cold-hearted. The political system is being beastified.

\subsubsection{Synonymy, antonymy}

These meaning relationships are also important in the sense that they reflect the way the speaker relates different or similar aspects of reality. These relations may be connected to ideological, moral, political, or even religious aspects.

We are going to analyze one example of synonymy from the speech by President Bush, and two cases of antonymy, one from this same text, and one from that of Bin Laden.

"...for all whose sense of safety and security has been threaten...". Very often, synonyms share a part of the meaning, but have some different connotations. Well, here we have a case of complete correspondence in meaning. It is the same word, one in the Anglosaxon version, and one in the Latin one. The difference between them is contextual. Security, as many words of Latin origin, is more commonly used in a formal context, whereas safety, as with most Anglo-saxon words, belongs to a more informal context. In this sense, the addressee could perceive safety as something that affects him in his everyday life, and security as a question of state since this word is not normally used in familiar and informal contexts.

However, this could almost be considered a case of repetition through addition that stands for the emphasis that the speaker is giving to this concept. This preoccupation on security is reinforced by the use of words related to this semantic field in the previous paragraph: emergency response plans, help, protect, precaution.

Antonymy in Bin laden's text is mostly reflected in the way he depicts the morals of the addressee and the morals of his opponents. I am going to concentrate on the dichotomy honor-treason. They are antonyms in a wide sense, since treachery is implied by dishonor. 
Thus, this is an antonymy by hyponymy. This act of treachery is also performed by his own people, who joined the infidels, "they have come out in force with their men and have turned even the countries that belong to Islam to this treachery." This contrast highlights their isolation. Also, in the text, he had been insisting on the idea that they were the victims and their enemy was an oppressor. Now, he is also implying that their enemies are morally inferior. This is one more argument to justify the terrorist attack.

"Today, our nation saw evil, the very worst of human nature, and we responded with the best of America, with the daring of our rescue workers, with the caring for strangers and neighbors who came to give blood and help in any way they could." Here, Bush is making a contrast between the enemy and themselves. The feature alluded to is morality as well. Morality separates humans from animals. The worst extreme of morality depicts the enemy: depravation. The best extreme is generosity and kindness. Notice the words rescue, caring, help.

This dichotomy may have two approaches. One depicts good emerging from evil, which is a way of not granting the enemy the satisfaction of total destruction, as well as moral support to the victims and the audience in general. This is a turning point from a negative to positive approach. Besides, this good emerged from evil through cooperation between citizens, that is, they united to overcome the damage. This is not the first time this topic had been used. Previously, in the Oklahoma city bombing, on April 19, 1995, this topic was employed. (Mitchell 2000). In the other approach, the deprived nature of the opponents is emphasized. This perspective may urge the population not to perceive them as people with a political end, but as deprived creatures who should not be listened to.

\subsection{ReLATiONAL VALUES OF VOCABULARY}

My aim in this section is to analyze the relational values of words. This has to do with the fact that the speaker's choice of words depends on and helps create social relationships between participants (Fairclough 1985). I will focus on euphemisms and formality.

\subsubsection{Euphemisms (politically correct and non-racist terms)}

Euphemisms have relational implications and reflect the position of the speaker in relation to some aspects that clearly define the social group to which the text is addressed. That is, they define the type of relationship established between producer and the addressee in terms of inclusion-exclusion.

The following example is from the RCP pamphlet, "A brown skinned woman stands at the red cross...her eyes scan the scene.... A young blue eyed man waits nervously for news of his lover." Clearly, the writer is avoiding the terms black and white. The terms used imply that the writer is not in favor of racism, since he has avoided words that belong to the racist discourse. The Communist goal is the abolition of social differences, and that type of discourse would not be coherent with their political precepts. They are establishing solidarity with their addressee. The profile of their reader is a person who has a political ideology oriented towards the left, and is against racism, chauvinism and materialism. They all go together because all of them imply the advantage of one group over the other. It is an attitude rather than a party to favor.

In the speech by Bush we also find some terms that, although they cannot be called euphemisms, belong to the so-called politically correct discourse, "The victims were in 
airplanes or in their offices: secretaries, business men and women,..." In the last years, the idea of correctness in the use of language has been acquiring a great importance, especially in the official discourse. It is this discourse that establishes the standard. In this speech in particular, we find an effort to display integration, "...all Americans from every walk of life unite..." In this sense, being politically correct acquires an especial importance not to exclude any group.

\subsubsection{Formality}

In English, formality is not marked by pronouns like in Spanish (tú-Usted) or in French (tu-Vous). However there are other means that imply this idea. The one that is going to be analyzed in this section is the origin of the vocabulary. As it has been explained before, words of Latin origin are used in formal contexts, whereas those of Anglo-saxon origin belong to the informal or familiar context. In order to see how these registers affect the relationship between participants, one of the texts is going to be briefly analyzed.

The speech by Bush contains both registers. At the beginning and in the end, where the melodramatic tone is found, the speaker uses an informal register. Nevertheless, in the second part, we find more formal words: precaution, response, appreciate, assistance, condolences. This is the part in which he performs his role of president as the head of the government and he acquires a position of authority over the addressee. Formality marks the distance in this point between the participants. In the end, he recovers the informality of the beginning. The melodramatic tone is recovered as well, and in this context he asks for the union of all members of the American community. At this point solidarity is recuperated and a more familiar tone is used.

\subsection{EXPRESSIVE VALUE OF VOCABULARY}

The expressive value of vocabulary reflects the evaluation of the speaker towards what he is saying. I will analyze the evaluation of the speakers in relation to one topic in particular in their speeches.

Bush. The topic that will be discussed is that of "Patriotism". The words used as a reference are nation (lines 7, 8, 14), country (line 8), and America(n) (lines 10, 11, 12, 15, $24,31,33,41,42,45)$. As it can be noticed by the number of times this term is used, this topic is very relevant in this discourse. Bush's evaluation of the idea of patriotism is very positive. Nation, country and America are associated with, strong, great, resolve, freedom, opportunity, values very much appreciated by American society. The speaker is offering an image of America connected to the American Dream and emphasizes what being American means according to that myth.

These values are being connected to his government as well. In this sense, we could say that, somehow, a transference takes place. The ideas of strength and determination are emphasized in the second part of the speech, where the speaker explains what he and his government are doing to solve the situation, "Our military is powerful", "The functions of our government continue without interruption. Federal agencies...are reopening..."

The speaker is appealing to the patriotic sense of the addressee to support the country and stand together (line 34) and unite (line 41). On the basis of the transference, this could be read as an appeal to support him as the head of the country. Not supporting him would mean to divide the country between those who do support him and those who do not. 
Bin laden. The term America is also very widely used in this text (lines 2, 3, 4, 7, 18, $26,31,32)$. However, for Bin Laden, this word does not convey the same implications. The words connected to it are butcher, killers, oppressor, and cowards. Nothing to do with greatness. This America is the enemy to be fought.

The concept of patriotism is also present. Here, nation (line 5) is related to honor (line 14), and innocence, innocent child (line 16). And this contrasts with the humiliation and degradation (line 5) that America brings forth.

$\boldsymbol{R C P}$. This is a Communist text, and as such, it contains many words related to the Communist discourse: imperialism, capitalism, power structure, exploitation, military machine. As it could be expected, they are all used in a very negative way. For instance, imperialism is related to crimes, and is depicted as cold-hearted. Capitalism is present through the expression capitalize in the clause, "The rulers capitalize on our pain" (line 45). A financial term related to a human traumatizing feeling. The implication is that capitalism does not care for the welfare of humanity, but about profit. This dehumanization of capitalism is emphasized with the use of the term machine to describe the different official bodies. For instance, military machine, term described as bloody. There are no surprises in this text.

\subsection{MetAPHORS}

Metaphors can be described, in a general approach, as a way of representing one aspect of reality in terms of another. Metaphors do not only exist in poetry or literature. We can find metaphors in all kinds of discourses, and according to Fairclough, some of them have ideological attachments. All three texts under study will be analyzed in this section.

Bush. One of the metaphors used by Bush is, "Terrorist attacks can shake the foundations of our biggest buildings, but they cannot touch the foundation of America. These acts shatter steel, but they cannot dent the steel of American resolve" (lines 9-11). These are two metaphors with similar structures. Both of them are divided into two contrastive sections. The contrast is based on affirmation versus negation. The modality expressed in the dichotomy can vs. cannot refers to capacity, and also to possibility. Thus, the power of both blocks is being measured in terms of delimiting what can be done and what cannot be done, and by whom. This measure is also reflected in the damage capacity of the verbs, shake-touch, shatter-dent. Thus, it could be said that power is established in terms of intensity.

In the first metaphor, the keyword is foundation. This term has different meanings. On the one hand, foundation is used in an architectural sense. It is referring to the objective part of the attack, two buildings were destroyed. On the other hand, it is alluding the more subjective field of values. In this sphere, this term refers to the moral basis of American values. The implication here could be that they are powerful enough to destroy something material, but America is more than buildings, it is a concept, and terrorists will never be able to destroy that with explosions.

The second metaphor is based on the term steel. In this case, the keyword has a triple dimension. As foundation, it is used in an architectural and a moral sense. However, steel has another implication, that of indestructibility. This implication is established through the 
traditional saying, "Hard as steel". Here, the ideals of American values are being expanded through the implication that they are impossible to break.

Bin Laden. The metaphor that will be analyzed here is a very traditional one, that of illness: "In these days, Israeli tanks infest Palestine - in Jenin, Ramallah, Beilt Jalla, and other places in the land of Islam". The topic of the illness could be explained in terms of a group damaging another group. One of them is reduced to the dehumanized position of an infection. The harmful nature of the occupation is emphasized through hyponymy. The Israeli soldiers are named by one of their weapons, their tanks. Also, one of the characteristics of infections is that they spread, and this idea is suggested with the catalogue of places that are being attacked. The Israeli community is depicted as a plague. If we take into account that the U.S.A. is the main supporter of the Israeli government, then this could be considered as an indirect attack to them.

$\boldsymbol{R} \boldsymbol{C P}$. In the RCP text, the metaphor of the rain is very recurrent, "...friends and colleagues are gone. Snatched away by a conflict that has brutally intruded into daily life from the heavens." (line 7), "U.S. bombs fall like rain." (line 11), "These imperialistswho have perpetrated countless crimes and rained havoc on the people of the world..." (line 24), "As long as they continue in power the horrors that come from their system will continue to rain from the sky." (line 67). The first example does not contain the word rain, but it is indirectly related to it and provides the connection between the event and the meteorological phenomenon. This connection is necessary for the transference of meaning. In example number two, we have a comparison rather than a metaphor in a strict application of the word, but this case will be analyzed as well on the basis of its contribution to the general image that is being created.

The rain has usually been a symbol of purification through water, of moment of change. Nevertheless, in this text, the visual impact of the airplains flying in the sky and crashing, and skyscrapers falling from their height to the groundfloor is being manipulated.

The rain has been a metaphorical inspiration for songs and popular sayings, "it's raining men", "it's raining cats and dogs." And it usually has an implication of abundance. Also, the weather is uncontrollable, and in this sense, the rain can have a component of helplessness in relation to what is going on.

This metaphor is used four times. In the first and the last case, it is related to chaos in America, whereas in examples two and three, the rain is related to chaos provoked by America in other places. The idea of agency is highlighted in example number three. Here, an intransitive verb such as "to rain", is transitivized. It becomes a material process where the agent is the U.S.A. and the affected participant is the people of the world. The implication, as usual in this text, is that they get what they deserve because of the government they have. This metaphor is very visual and in this sense, very effective. Texts $\mathrm{A}$ and $\mathrm{B}$ were speeches on TV, whereas $\mathrm{C}$ is a pamphlet. This effectiveness compensates somehow for the handicaps that written texts have over visual ones in modern politics.

\section{CONCLUSION}

To sum up, in moments of conflict, justification is the usual device used to create a cause and obtain the support of the population to fight for it. For this reason, leaders from different countries in different historical moments have tried to get the approval of their 
community in their decisions, especially when violence is required. The image of the heroic victim is enhanced while the opponent is portrayed in negative terms, and the terms are oriented towards the detachment of the community of the speaker from the opponent. Maybe this segregation of the opponent is meant to achieve a lack of remorse when attacking him. The justification for the attacks could be summarized as: they are bad and we are good. We have the right and the obligation to fight them. It has been used throughout history and it still is. Consequently, I must conclude that this is one of the most effective tools of persuasion. We do not need a great effort in observation to witness in any moment of our lives that it is being used and according to the reactions that we can see around us, it works.

\section{WORKS CITED}

BALL, M.A. (2000) "Political language and the Search for an Honorable Peace: Presidents Kennedy and Johnson, Their Advisers, and Vietnam Decision Making" in C. De Landtsheer, And O. Feldman, Beyond Public Speech and Symbols. Explorations in the Rhethoric of Politicians and The Media, Westport, Praeger, 2000.

BORMANN, E.G. "A Fantasy Theme Analysis of the Television Coverage of the Hostage Release and the Reagan Inaugural", Quarterly Journal of Speech, 68, pp. 133145, 1982.

LANDTSHEER, C. De \& FELDMAN, O. (eds.) Beyond Public Speech and Symbols. Explorations in the Rhetoric of Politicians and the Media, Westport, Praeger, 2000

FAIRCLOUGH, N., Language and Power, London, Longman, 1989.

FAIRCLOUGH, N., Critical discourse Analysis: the Critical study of language, London, Longman, 1995.

MITCHELL, T. L., "Visions of a Tragedy: Symbolic Convergence in the Print Media Coverage of the Murah building Bombing in Oklahoma City", in C. De Landtsheer, \& O. Feldman, Beyond Public Speech and symbols. Explorations in the Rethoric of Politicians and the Media, Westport, Praeger, 2000.

STIFF, J.B., Persuasive Communication, N.Y., The Guilford Press, 1994.

VAN EEMEREN, F.H., GROOTENDORST, R. \& KRUIGER, T. Of Argumentation Theory. A Critical survey of classical Backgrounds and Modern Studies, Dordrecht, Foris Publications, 1987.

VAN EEMEREN, F.H. \& GROOTENDORST, R., Argumentation, Communication, and Fallacies, Hillsdale, Lawrence Erlbaum Associates, Publishers, 1992.

\section{SPEECHES}

"In President George W. Bush's own words", The speech made by President Bush on the evening of September 11, 2001. Speech delivered from the Oval office.

"Text of Osama Bin laden's taped remarks", Aired on an Arab television Station after the US and British strikes Sunday. October 2001. 
"Sinners in the Hands of an Angry God", Jonathan Edwards to his Congregation in Enfield, Massachussets, July 8, 1741.

"Inaugural Address as U.S. President", John F. Kennedy, 1961.

\section{PAMPHLETS}

"The Horrors that come from this Horrible system". RCP, USA, September 14, 2001.

"Anti-imperialism and the anti-war movement". Detroit Worker's Voice, January 10, 2003 \#34.

"To hell with Bush and Hussein: Stand up against the U.S. war drive against Iraq!" by Communist Voice Organization, Detroit, October 26, 2002.

\section{NEWSPAPERS}

Latino, Latino Press inc. Detroit \& Toledo, Vol. 10, April 3, 2003

La Prensa, Ohio \& Michigan, Vol. 33, n. 3, April 2, 2003 
